\title{
Abbreviations to Avoid in Documentation
}

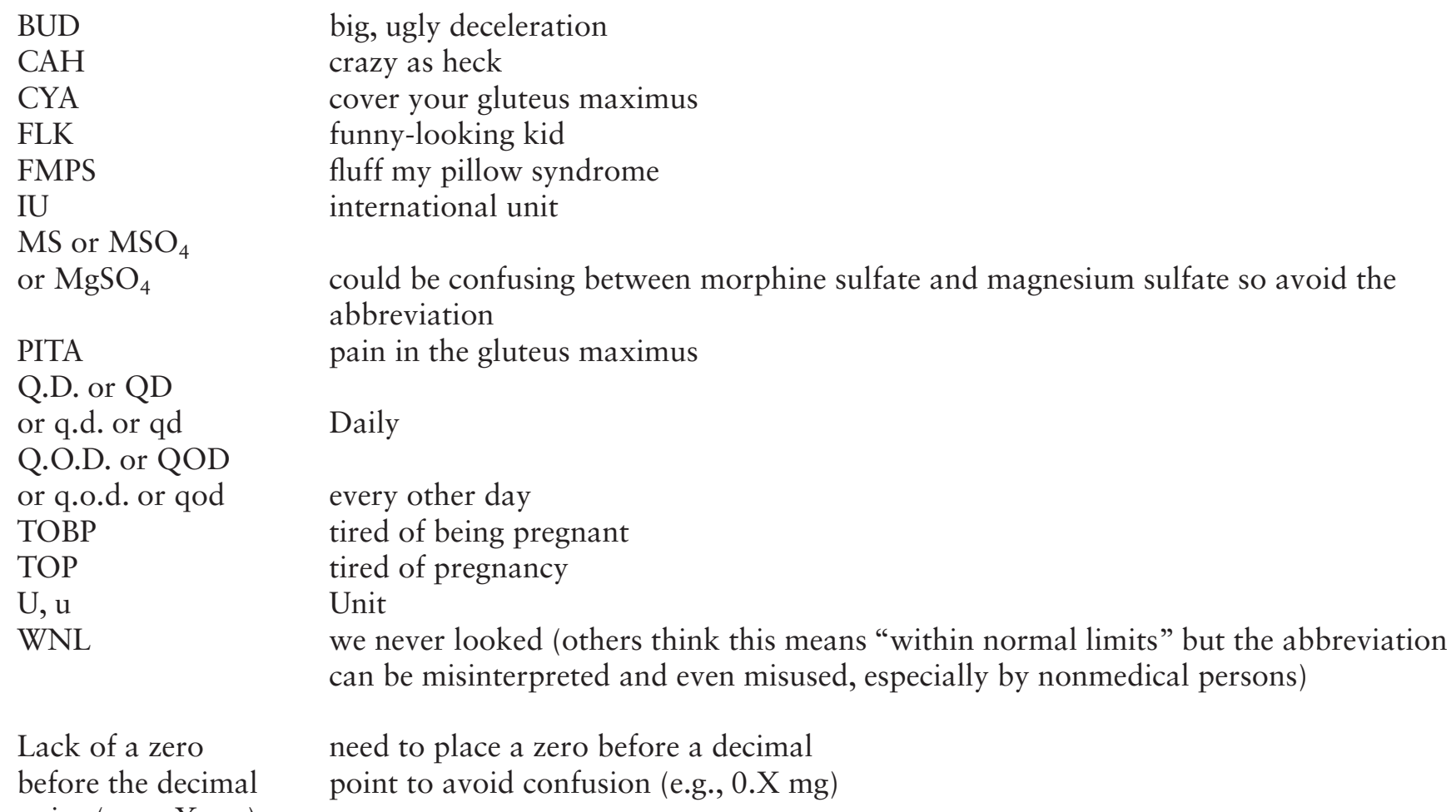

